\title{
PRODUCT POLICY AND MANAGEMENT
}

\author{
Michael J. Baker \\ Professor of Marketing, University of Strathclyde \\ Ronald McTavish \\ Senior Lecturer in Marketing, University of Strathclyde
}

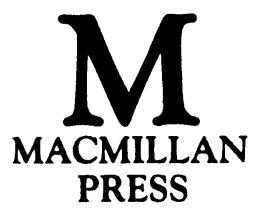


All rights reserved. No reproduction, copy or transmission of this publication may be made without written permission.

No paragraph of this publication may be reproduced, copied or transmitted save with written permission or in accordance with the provisions of the Copyright Act 1956 (as amended), or under the terms of any licence permitting limited copying issued by the Copyright Licensing Agency, 33-4 Alfred Place, London WC1E 7DP.

Any person who does any unauthorised act in relation to this publication may be liable to criminal prosecution and civil claims for damages.

First edition 1976

Reprinted 1983, 1988

Published by

THE MACMILLAN PRESS LTD

Houndmills, Basingstoke, Hampshire RG21 2XS and London

Companies and representatives throughout the world 


\section{Contents}

Preface vii

List of Tables $\quad$ ix

List of Figures $\quad$ x

Chapter 1 The Product in Theory and Practice 1

Introduction 1

The Product in Economic Theory 4

Product Differentiation $\quad 6$

The Product Life-Cycle Concept 10

Chapter 2 Product Planning 15

Introduction 15

The Meaning and Scope of Product Planning 15

Top Management's Contribution to the Product-
Planning Process

Product Policies and Product Objectives as Guides to Product Planning 19

Product Planning and Marketing Strategy 19

Some Reasons for Lack of Product Planning 24

Product Planning - Some Tentative Generalisations 26

Chapter 3 Marketing Strategy and Product Policy 28

Introduction 28

The Concept of Limited Strategic Alternatives 29

Selecting a Marketing Strategy 32

Market Segmentation $\quad 34$

Measuring Consumer Differences $\quad 36$ 
iv CONTENTS

Basic Product Policies

Summary $\quad 44$

Chapter 4 Identifying Market Opportunities 45

Introduction $\quad 45$

The Nature of Marketing Opportunity 46

Identifying Marketing Opportunites 47

The Delphi Model 48

Scenario Writing 49

Extrapolative Techniques $\quad 50$

Structuring Methods 51

Auditing the Company's Status 53

The Collection of Data $\quad 54$

Field Research 58

Chapter 5 Product Management 61

Basic Approaches to the Management of Products 61

Product Managers vs Market Managers 62

The Product Manager $\quad 65$

Responsibilities of the Product Manager 66

The Product-Manager System in Practice 68

Managing the Product Manager's Interfaces $\quad 70$

Prescriptive Remedies $\quad 72$

$\begin{array}{ll}\text { Conclusion } & \mathbf{7 7}\end{array}$

Chapter 6 The New-Product Development Process 78

Introduction $\quad 78$

New-Product Evolutionary Cycle $\quad 79$

Idea Generation $\quad 80$

Idea Screening $\quad 81$

Idea Evaluation $\quad 82$

Technical Development $\quad 83$

Testing $\quad 84$

Commercialisation $\quad 85$

Characteristics of the Evolutionary Cycle 86

Organisation of New-Product Development - The Need for Integration $\quad 87$

Problems of Organisation in Practice 91 
Chapter 7 The Generation and Evaluation of New-Product Ideas

Introduction

Creativity in the $\mathbf{R}$ and $\mathbf{D}$ Laboratory

Idea Generation by non $\mathrm{R}$ and $\mathrm{D}$ Personnel

Selected Internal Sources

Selected External Sources

104

Screening and Evaluating New-Product Ideas $\quad 110$

Conclusion

Chapter 8 New-Product Design and Technical Development

Introduction

Designing for the Needs of the Market

Problems of Internal Generation of Designs

The Importance of Design/Marketing Co-ordination 128

Technical Development

The Importance of Technical Development/Marketing Co-ordination

Conclusion

Chapter 9 Commercialisation and Beyond

Introduction

Concept Testing

Product Testing

Test Marketing

Launching New Products

Product Retiral

Chapter 10 American Motors Corporation-A Case Study in Product Policy

Introduction

Product Policy in the U.S. Automobile Industry 158

American Motors and the 'compact car' 162

The Big Three Revise their Strategy 165

American Motors in the 1960s 167

Summary

Notes and References 


\title{
MACMILLAN STUDIES IN MARKETING MANAGEMENT
}

\author{
General Editor: Professor Michael J. Baker, \\ University of Strathclyde
}

This series is designed to fill the need for a compact treatment of major aspects of marketing management and practice based essentially upon European institutions and experience. This is not to suggest that experience and practice in other advanced economies will be ignored, but rather that the treatment will reflect European custom and attitudes as opposed to American, which has tended to dominate so much of the marketing literature.

Each volume is the work of an acknowledged authority on that subject and combines a distillation of the best and most up-to-date research findings with a clear statement of their relevance to improved managerial practice. A concise style is followed throughout, and extensive use is made of summaries, checklists and references to related work. Thus each work may be viewed as both an introduction to and a reference work on its particular subject. Further, while each book is self-contained, the series as a whole comprises a handbook of marketing management.

The series is designed for both students and practitioners of marketing. Lecturers will find the treatment adequate as the foundation for in-depth study of each topic by more advanced students who have already pursued an introductory and broadly based course in marketing. Similarly, managers will find each book to be both a useful aide-mémoire and a reference source.

The titles so far published in the series are:

Michael J. Baker etal., Marketing: Theory and Practice

Michael J. Baker and Ronald McTavish, Product Policy and Management

J.R. Bureau, Brand Management

Gordon R. Foxall, Consumer Choice

Roy W. Hill and T.J. Hillier, Organisational Buying Behaviour

Frank Jefkins, Public Relations in Marketing Management

F. Livesey, Pricing

J. M. Livingstone, International Marketing Management

J. M. Livingstone, A Management Guide to Market Research

Ronald McTavish and Angus Maitland, Industrial Marketing 


\section{Preface}

The product (and/or service) plays a central role in the activities of all organisations, for it is the medium through which they seek to achieve their dual objectives of maximising both consumer and organisational satisfaction. Thus, while this book is concerned primarily with the management and marketing of the products manufactured by profit-orientated firms, it is believed that many of the principles and policies discussed are of equal relevance to non-profit organisations.

While the book concentrates on managerial problems of product planning and organisation, the product-planning issue is first of all placed in an historical/theoretical setting. On this basis, the main concern with the nature of management problems, and how to overcome them, is pursued. Thus the book has a strong normative interest, namely to develop a practically useful framework of concepts and methods which will be valuable to managements in this vital marketing-mix area.

The broad approach of the book is partly descriptive, partly analytical. In recent years various writers have examined selected aspects of product planning, notably the management of new products, design management, test marketing, and so on. A major objective of this book is to synthesise and unify these into a concise, over-all approach to solving the total product-planning problems of the firm. In pursuing this approach we have attempted to impart a practical thrust, seeking realism in our statement of the product-planning problem in its different aspects. The approach is thus directly related to solving real-world business problems. Indeed, much of the material is developed from various live problems the authors have themselves investigated.

In short, the book provides practical guidance on methods for product-planning decision-taking in the firm. 


\section{viii PREFACE}

It is addressed to all working managers concerned with such decisions, but will also commend itself to senior managers concerned with the product aspect of corporate strategy. In addition, teachers and students of marketing management will find the book a useful addition to their libraries.

The authors wish to acknowledge not only the many sources cited in the text but also the multiplicity of ideas contributed by both practitioners and academic colleagues which lack a specific reference.

Finally, we would like to record our thanks to our longsuffering secretaries, Miss C. M. Paterson and Mrs M. Murphy, for all their efforts in preparing a legible manuscript, and to our families for their forbearance and encouragement during the writing of it.

Strathclyde University

July 1975
Michael J. Baker

Ronald McTavish 


\section{List of Tables}

Table 2.1 Checklist for setting long-range corporate objectives

Table 3.1 Classification of new products by product objective

Table 4.1 Steps in auditing the competitive environment 55

Table 4.2 Literature sources $\quad 57$

Table 5.1 Job specification for a product manager $\quad 74$

Table 7.1 Characteristic table 101

Table 7.2 New-product journals 108

Table 7.3 Qualitative screening process 112

Table 9.1 Advantages and limitations of productconcept testing

Table 10.1 U.S. automobile sales, 1971-2 170 


\section{List of Figures}

Figure 1.1 The product life cycle 11

Figure 1.2 The product life cycle (redrawn) 12

Figure 1.3 Consumer-goods manufacturers' dependence on new products 13

Figure 1.4 Industrial-goods manufacturers' dependence on new products 13

Figure 2.1 Desert-and-oasis map for selected marketingmixes

Figure 3.1 The 'attack' alternatives 30

Figure 5.1 Basic approaches to product management 63

Figure 6.1 Organigram for change 90

Figure 7.1 Evaluation chart for product R and D projects 